\title{
Diretrizes curriculares, gestores de saúde, gestores de educação, pesquisadores e o hospital de ensino: a polifonia ruidosa de uma crise de identidade
}

\author{
Curricular guidelines, health and educational \\ administrators, researchers, and the teaching \\ hospital: point and counterpoint in an identity \\ crisis
}

Francisco Barbosa Neto

\begin{abstract}
A crise de sustentabilidade dos hospitais de ensino se arrasta desde o início dos anos 1970, quando estes ainda eram poucos. A de legitimidade eclodiu por ocasião dos debates sobre a Lei Orgânica da Saúde, entre 1988 e 1990, e foi parcialmente superada no artigo 45 da Lei 8.080/90 e pela fundação da Abrahue. A de hegemonia ficou patente em 2001, com a aprovação das diretrizes curriculares e o deslocamento da centralidade do hospital na formação médica. Mas, de todas as crises, a mais antiga talvez genética - e mais persistente é a de "identidade". Crise institucional por excelência que compõe e sustenta as demais. Qual o lugar do hospital de ensino na universidade? Órgão suplementar da reitoria ou mais uma "dor de cabeça" do reitor? Prolongamento de uma tradição da escola médica ou "campo de hierarquização" das profissões de saúde? Qual o lugar do HE no SUS? Hospital de referência do sistema ou "apenas um hospital mais dispendioso" para o gestor? Avaliador de tecnologias em saúde ou "gerenciador de sucateamento e defasagem tecnológica"? Qual o lugar do HE na pesquisa? Laboratório privilegiado de "pesquisa clínica" ou "estratégia de marketing" da indústria farmacêutica e de equipamentos? Qual o lugar do HE na modelagem de gestão de organizações complexas? Lócus privilegiado para desenvolvimento da gestão de sistemas complexos ou "trincheira de corporativismo replicante"? Qual o lugar do HE para o paciente? Local de esperança de recuperar sua saúde ou onde não passará de um número ou um "caso interessante"? E para o aluno? Onde aprende a "cuidar de pessoas gravemente enfermas" ou onde aprende preferentemente a "manejar tecnologias" descoladas da realidade da prática predominante no sistema de saúde? E para o professor? Local de exercício das "melhores evidências científicas" ou mero campo de reprodução do que aprendeu com seus antecessores?

Essas e muitas outras perguntas poderiam ser formuladas à exaustão, mas só reforçariam o universo de paradoxos e contradições que subjaz na crise de identidade dos HEs. Do torneiro mecânico da unidade de manutenção do HE ao presidente da República, numerosos outros atores se envolveram nessa crise. Como toda crise, esta teve seu "ponto de mutação", ocorrido entre 2001 - com o Parecer CES/CNE nำ1.133, de 07 de agosto, que analisou e fundamentou as diretrizes curriculares para a área da saúde - e 2003 - com a Portaria Interministerial no 562, de 12 de maio, que criou a Comissão Interinstitucional "visando formular política para os hospitais universitários e de ensino". Quatro ministros de Estado - Educação, Saúde, Ciência e Tecnologia e Planejamento, Orçamento e Gestão - foram signatários deste ato legal que envolveu, além de representantes dos respectivos ministérios, representações do Conselho Nacional de Saúde, do Conass, do Conasems, da Abrahue, da Andifes e da Abem, entre outras entidades interessadas no assunto hospital de ensino.
\end{abstract}


A partir de 2004, uma série de Portarias Interministeriais e do Ministério da Saúde regulamentou a política formulada pela Comissão Interinstitucional, e iniciou-se o processo de certificação e de contratualização dos hospitais de ensino. Mas o desenho desta política permite ir muito além da emissão de uma "certidão" com prazo de validade e do neologismo de um "termo de contrato", embora dirigentes universitários, diretores de hospitais e gestores do SUS não raro façam esta redução. O núcleo estruturante desta política é o seu caráter sistêmico, sustentado em quatro pilares interdependentes: assistência, ensino, gestão e pesquisa. Indicadores de desempenho precisam ser desenvolvidos e aperfeiçoados para qualificar a gestão do HE nas negociações de metas com os gestores do sistema, procurando ir além das tradicionais metas assistenciais. Outro vetor estruturante seria a capacidade dos gestores estaduais para desdobrar e adequar a política no âmbito da UF, trazendo inovações ao sistema. Infelizmente, decorridos quase seis anos do início do Programa de Reestruturação dos Hospitais de Ensino, uma fração mínima dos Estados da União conseguiu implementar uma política estadual consistente e coerente com a aprovada pelo nível central. A maioria fica próxima da omissão ou do mero tratamento burocrático por ocasião das visitas da equipe técnica de certificação. Para agravar mais ainda a situação, a Comissão Interinstitucional, que deveria se reunir periodicamente para avaliar a implementação do programa, permaneceu mais de dois anos sem promover tais encontros.

Por outro lado, quatro importantes eventos de ocorrência recente trazem alento e oxigênio para a retomada dos avanços deste programa. Primeiro, a Auditoria Operacional modalidade Fiscalização de Orientação Centralizada (FOC), do Tribunal de Contas da União, em um trabalho de fôlego e bem estruturado, com uma amostra significativa de nove dos 46 hospitais de ensino vinculados à Ifes, situados em oito Estados da Federação, e que resultou no Acórdão nํ⒉813/2009 na sessão ordinária de 25 de novembro de 2009 do TCU. Segundo, a retomada das reuniões da Comissão Interinstitucional, já com calendário para todos os meses de 2010, e com a desafiadora tarefa de elaborar minutas para a revisão e atualização dos processos de certificação e contratualização. Terceiro, a publicação das Portarias Interministeriais $\mathrm{n}^{\circ} 40$ e 41, de 08 de janeiro de 2010, que reinstituem a Comissão Interinstitucional de Hospitais de Ensino e atualiza sua composição, respectivamente. E, por último, mas não menos importante, o Decreto no 7.082, de 27 de janeiro de 2010, do presidente da República, que institui o Programa Nacional de Reestruturação dos Hospitais Universitários Federais (Rehuf), destinado à reestruturação e revitalização dos hospitais das universidades federais, integrados ao Sistema Único de Saúde (SUS), nos termos do artigo $4^{\circ}$ da Lei 8.080.

Finalmente, visando evitar novas dispersões, desencontros ou descaminhos deste programa, bem como distorções motivadas por segmentação bairrista ou pela lógica de que "a farinha é pouca, meu pirão primeiro", talvez tenha chegado o momento de reeditar uma nova e ampliada Ciplan que desempenhou papel significativo na implementação das Ações Integradas da Saúde (AIS) na transição do regime autoritário até a gestação do SUS, composta pelos secretários executivos dos ministérios envolvidos e pelos presidentes do Conass e Conasems, como garantia de continuidade e condução harmônica desta relevante política. 